University of Michigan Law School

University of Michigan Law School Scholarship Repository

Articles

Faculty Scholarship

1872

\title{
Power of Judiciary to Declare a Law Unconstitutional
}

Charles A. Kent

University of Michigan Law School

Available at: https://repository.law.umich.edu/articles/549

Follow this and additional works at: https://repository.law.umich.edu/articles

Part of the Constitutional Law Commons, Courts Commons, Legislation Commons, and the Tax Law Commons

\section{Recommended Citation}

Kent, Charles A. "Power of Judiciary to Declare a Law Unconstitutional." Am. L. Reg. n.s. 11 (1872): 729-36.

This Article is brought to you for free and open access by the Faculty Scholarship at University of Michigan Law School Scholarship Repository. It has been accepted for inclusion in Articles by an authorized administrator of University of Michigan Law School Scholarship Repository. For more information, please contact mlaw.repository@umich.edu. 


\title{
AMERICAN LAW REGISTER.
}

\author{
DECEMBER, 1872.
}

THE POWER OF THE JUDICIARY TO DECLARE A LAW UNCONSTITUTIONAL.

The judiciary has no power to declare a law unconstitutional unless it conflicts with some provision of the State or Federal Constitution.

It will be the purpose of this article to show the reasonableness and meaning of this principle.

To many lawyers a discussion of the subject will appear unnecessary, because the doctrine stated seems perfectly established by the decisions.

But it has been recently disputed by high authority. Judge COOLEY, in the preface to the second edition of his able work on Constitutional Limitations, says that he has endeavored to point out "that there are on all sides definite limitations which circumscribe the legislative authority independent of the specific restrictions which the people impose by their State Constitutions." And similar views are maintained by Judge REDFIELD, in the American Law Register for March, 1871, p. 161 et seq.

And some courts which assert the principle for which we contend, in the most unqualified terms, assert, also, as a provision of constitutional law, not founded upon any specific constitutional inhibitions, the doctrine that taxation can be only for a public purpose, and that an attempt to tax for a private purpose is void.

Vor. XX.-47. 
That, as a matter of justice, taxation should be employed only for a public purpose, that is, a purpose which the community taxed is interested in accomplishing, is so obvious a truism that we presume it was never doubted. Probably no legislator ever voted for an act imposing taxation, except on the ground that it would conduce to some purpose which he deemed public.

But obviously just as is the principle, its assertion by the judiciary as a test by which to try the validity of acts of the legislature, is inconsistent with the doctrine that no act of the legislature van be declared roid, except in conflict with some specific constitutional provision. It is said that the very definition of taxation shows that it must be for a public purpose, and that an attempt to tax for an object not public is not taxation, but robbery, and, therefore, void. This is plainly limiting the power of the legislature by the definition of a word-a definition made by the lexicographer, or by the usage which he followed in giving the definition.

Where the validity of an act of the legislature depends upon the interpretation of a constitutional provision, it may depend upon the definition of the words used in such provision; but to assert that in any other case an act of the legislature can be controlled by definitions of words not used in it, is to set up a standard of judgment outside of the written Constitution.

Most of the courts which assert as a principle of constitutional law that taxation must be for a public purpose, qualify the assertion by saying that the matter is so far within the legislative discretion that if the taxation in question can in any degree be promotive of the public welfare, then the legislative decision is conclusive upon the courts. This qualifcation, consistently adhered to, takes away almost all practical power from the assertion of the principle; for the legislature will, perhaps, never vote the public money except for some object which they claim to be public, and it can very seldom, if ever, happen that a court can say as a matter of law that the expenditure authorized can, by no possibility, be beneficial to the public.

But the assertion of the principle with the qualitication is 
still in direct conflict with the doctrine that no act of the legislature can be declared void unless in conflict with some specific constitutional provision, and it has given occasion for some courts to pass from the assertion of a principle thus practically unimportant to the announcement of doctrines having a most important practical bearing upon the respective powers of the judicial and legislative departments of government.

In the recent cases of White $\nabla$. The Sheboygan $R$. R. Co., 9 Am. L. R., N. S. 156, and The People v. Salem, 9 Am. I. R., N. S. 487, S. C., 20 Mich. 452, the highest courts of Wisconsin and Micbigan have declared that the giving of public money to private corporations, to aid in the building of railroads, is unconstitutional. They did not undertake to determine that the railroads to be built could by no possibility benefit the communities to be taxed, but they say in effect that the manner devised by the legislature of accomplishing the public benefit sought is unconstitutional.

In the case of the Garrard County Court v. Kentucky River Navigation Company, 10 Am. L. R., N.S. 151, the highest court of Kentucky held that the improvement of a navigable river was not of such local public benefit as to sustain an act of the . legislature, authorizing the County of Garrard, through which the river runs, to tax. itself for this purpose. The court, in this case, did not undertake to say that the improvement in question would not be a local benefit to Garrard county, but that it would not be such a local benefit as would justify county taxation.

If the principles sought to be established by these courts are sound, then courts, independent of specific constitutional restrictions, can determine, at least negatively, what objects are of sufficient public importance to justify taxation, and also the manner in which the public aid may be afforded. They can thus determine the objects of government, since only by taxation can any governmental object ba accomplished, and the method by which these objects shall be carried out. The importance of the principles thus announced is shown by the fact that while there is the greatest unanimity in the view that taration should be used only for a public purpose, there 
is the greatest variety in opinion and practice as to the objects for which the public should undertake to provide and the manner in which the needed provision should be made. If these matters are all to be left to the final determination of the judiciary, it will constitute a great enlargement of their powers.

Another limitation upon the power of the legislature is derived by some courts from the constitutional provision by which the powers of government are divided into legislative, judicial and executive, and the officials of each department are vested with its powers. It is conceded by all that this provision excludes the legislature from exercising judicial or executive powers, since these powers are granted to other departments. It is further said that under this provision the Legislature can exercise only legislative powers, and this also we admit, since there are no other powers known to government save judicial and executive, and from these the legislative is excluded. Butitis further contended that legislative power is something less than the power of making any law which the legislature deem proper-that there are restrictions upon it not contained in specific consțitutional inhibitions, but derived from the principles of justice or the nature of free government. If these restrictions were founded at all on the meaning of legislative power, then, as based on a constitutional provision, they would not be opposed to the doctrine for which we contend, but legislative power so clearly means the power of making laws irrespective of the subjects or the character of the laws, that it is idle to find limitations in these words. The limitations sought to be found here are, then, clearly outside of any constitutional provision, and must fall, if the judiciary have no power to declare an act void unless in conflict with some provision of the Constitution.

We have thus far undertaken to show the danger which exists of the infringernent of the principle with which we started. We now proceed to our main purpose of showing its meaning and reasonableness. And first, of its meaning.

1. It does not menn that an act of the legislature cannot be declared void unless expressly forbidden by some constitutional provision. An implied prohibition may be as clear 
as an express one, and if so, should be as certainly enforced. But in such cases, the provision which contaius the implication should be pointed out, and the implication should be derived only from a fair interpretation of the language used.

2. It does not imply that all proper limitations of legislative power are found in the Federal Constitution and that of any State. There may be other limitations of great importance, whose justice seems perfectly evident to all clear-headed political reasoners. Such limitations should be urged upon the legislature with such force as their merits cleserve. If disregarded, and the evil which results is wide-spread and great, the people should be urged to introduce into their constitutions the needed limitations.

3. It does not imply that the legislature may not do injustice not forbidden by the Constitution. Scarcely any law of general application is passed which does not do injustice to some one. And a law which operates in the fairest possible way will often seem unjust to those whom it burdens. It does, however, imply that the injustice in such cases is one as to which there is no relief from the determination of the legislature. The highest courts will often seem to suitors to commit great injustice, but from their decisions there is no appeal. And the injustice which comes through laws not forbidden by the Constitution, is an injustice which the courts have no right to remedy.

4. It does not imply that the citizen is always bound to obey every act of the legislature not in conflict with some provision of the constitution. An act not unconstitutional may be so unjust as to justify the exercise of the riglat of revolution, or it may be so ridiculous as to justify treating it with silent contempt. If an act of the legislature of $\mathrm{New}$ York should impose upon the city of New York, for municipal purposes, a tax which in one year should equal the entire value of all the property in the eity, this wond justify rebellion. If the same legislature should pass an act prescribing particularly the fashion in which eneh inhabitant of the city shonld dress, it would properly be treated with utter neglect and contempt. But in neither case, in the absence of 
constitutional provisions upon the subject, would there be any rightful appeal to the judiciary.

5. The principle for which we contend does mean that in deciding upon the constitutionality of an act of the legislature, the judiciary are confined to an interpretation of the act, and to an interpretation of the specific constitutional clauses which the act is alleged to infringe, and that only where the fair interpretation of the latter is in conflict with the fair interpretation of the former, can the act be set aside, and that to this rule there are absolutely no exceptions. It confines the work of the judiciary to that which is alone their proper province, viz., the work of interpreting the law, and applying it to the facts of the case before them.

The reasonableness of the rule that the judiciary cannot declare an act of the legislature unconstitutional unless in conflict with some specific provision of the Constitution, will appear from comparing the arguments in its favor with those against it.

The arguments in its favor can be reduced to these:

1. It is impossible to find any satisfactory basis for the existence of a power in the judiciary to declare void acts of the legislature, except as they are in conflict with the written Constitution. The power to set aside acts of the legislative body does not to belong the judiciary in England. It is, we believe, of purely American growth. It is wholly derived from the written constitution established here. It was first asserted as a necessary implioation from the fact that the written constitutions are deolared to be the supreme law, and must, as a consequence, render nugatory any legislative act in confliot with them. The duty of the judioiary to interpret the law made it neosssary for them to interpret both the legislative aot and the supreme law of the Gonstitution, and where there was a conflict, to declare the pre-eminence of the latter. The power of the judioiary to set aside aots of the legislature being thus wholly derived from writton constitutions, must fail where these fail. It cannot be extended beyond the source from which it had its origin.

2. The rule which we seek to maintain is the only one which can give that certainty which is one of the very high- 
est requisites of human law. It is as important that those who must suffer the consequences of a mistake as to the law, should be able to ascertain what it is before acting, as that the law should be wise and just.

But if acts of the legislature can be set aside by the judiciary bəaxuse in conflict with fundamental principles not expressed in the written constitutions, who is able authoritatively to declare what these prineiples are-what the judiciary in a given case will decide them to be? How can the legislature know when they are keeping within the proper boundaries, and so m.zking laws which will stand? And where shall the judiciary themselves look to ascertain these principles? If they say that leyislative power does not extend to the making of all laws not forbidden by the Constitution, where is the line which shall divide those which are within the legislative power, from those which are without it? Is usage to determine this line? If so, what must be the nature and extent and duration of this usage? If it lies in the power of the judiciary, independent of constitutional provisions, to say that a certain method of accomplishing a purpose acknowledged to be public, is unlawful, though adopted by the legislature, or that certain objects which the legislature have determined to be worthy of public support are beyond the sphere of governmental aid, where will they find the line which is to separate the methods or the objects which are unlawful from those which are not? It will be admitted that no such line can be found, and that no principle can be stated upon which the judiciary will agree, which will determine the limits of the power elaimed. The consequence is that the assertion of such indefinite power throws the whole subject of constitutional law into confusion and uncertainty. We venture to say that a large proportion of the difficult questions of constitutional law existing to-day, arise out of the attempt of the judiciary to ect up some standard of judgment outside of the written Constitution. The practical consequences of this uncertainty are disastrous. Legislatures must legislate upon subjects, or in methods which transgress some men's notions of the proper sphere of government. Business must be done based upon this legislation. Either 
it must go forward subject to the risk of being all set aside by judicial decision, or it must be suspended until judicial decision bas beeu obiained. The evil of either course may be very great.

3. It is only by maintaining the rule that the judiciary cannot declare an act of the legislature void unless it is in $\Leftrightarrow$ nfict with some provision of the written Constitution, that the line between legislative and judicial powers can be kept up. The separation of these powers, and the intrusting of them to different classes of officials, are regarded as very important by all our political writers. If the judiciary may set aside acts of the legislature because in conflict with principles whose determination is left to their sole unguided judgments, what hin.lers them from gradually assuming the power of putting a negative upon every act of the legislature, which, in their judgment, is unjust or unwise, and so having a very large control over the legislative power? The tendency of all men is to put the largest interpretation upon their own powers. This tendency in the legislature or executive may be checked by the judiciary. But what, save a strict adherence to the written Constitution, can check the judiciary?

The arguments against the view of constitutional law which we seek to maintain seem reducible to this one. The legislature will pass laws not forbidden by the provisions of the written Constitution, which are yet so unjust, or so contrary to the theory of free governments, as to do great evil, and the evil can be restrained only by giving the judiciary power to declare such laws void. This argument assumes that the judiciary are better judges than the legislatures of the principles of govermment, or of justice, and that the decisions of legislatures upon these subjects are not to be trusted-an assumption which, as a matter of fact, is sometimes true, and sometimes not true, but which at any rate comes with a very pour grace from the judiciary. It is fo:mded on a distrust of our theory of government, which commits the making of its laws to men who are often quite ignorant of many things which law-makers shonll know. We do not doubt that legislatures may often do mueh evil by the passage of acts not in conflict with the provisions of the Con- 
stitution, and that a part of this evil may sometimes be remedied by the assumption by the judiciary of a power to declare such acts void; but the assumption of this power may lead to greater evils than it can cure. At the best, it gives but an appeal from the judgment of one branch of the government to that of another, with no certainty that the latter will be better than the former. And the destruction of vested rights, which comes from the setting aside by the judiciary of an act generally acted upon as valid, may often produce greater injustice than the sustaining of the law, however contrary to fundamental principles. The mistakes made by the legislature can generally be easily corrected. New legislators can be speedily elected, who will repeal a law generally regarded as opposed to right principles of government, and a new constitutional amendment may be made without much difficulty to restrain future legislatures. But the mistakes of the judiciary in exercising powers to which they are not entitled are not so easily corrected. The acknowledged powrer of the judiciary to set aside acts of the legislature in conflict with constitutional provisions is fraught with such serious danger of evil that it is admitted by all that it should be exercised only in very plain cnses. But how much greater is the danger if such acts may be set aside because in conflict with principles so vague that it is impossible to define them beforehand, and so unsettled that an'inquirer cannot be told where to look for them!

C. A. Kent.

\section{COUNTY SUBSCRIPTIONS TO RAILROAD COR- PORATIONS.}

Is the subscription of stock to a railroad corporation, by a county, legal and valid because a majority of those voting at an election held in pursuance of a special statute, to determine whether such subseription shall be made, lave voted in favor of the proposition? 